\title{
Yaygın ve Yaygın Olmayan Sirke Çeşitlerinin Antioksidan Kapasite Düzeylerinin Değerlendirmesi
}

\author{
Metin KONUŞ*, Can YILMAZ, Doğan ÇETIN \\ Van Yüzüncü Yıl Üniversitesi, Fen Fakültesi, Moleküler Biyoloji ve Genetik Bölümü, 65080, Van \\ (ORCID: 0000-0002-9953-1375) (ORCID: 0000-0002-0028-6614) (ORCID: 0000-0002-5733-4007)
}

\begin{abstract}
Öz
Sirke, mayalanabilir farklı hammaddeler kullanılarak elde edilen bir fermantasyon ürünüdür. Eski zamanlardan beri birçok uygarlık tarafindan kullanılan sirke, mutfaklarda tatlandırma ve dezenfeksiyon gibi birçok işleve sahiptir. Sirke içerisinde barındırdığı çeşitli fenolik bileşikler, aminoasitler, vitaminler, organik asitler gibi maddeler sayesinde antimikrobiyal, antioksidan, antidiyabetik ve antikarsinojenik özellikleri ile sağlık üzerinde de birçok faydalı etkiye sahiptir. Bu çalışmada yaygın olarak marketlerde bulunan üzüm, elma ve nar sirkelerinin yanı sıra nadir bulunan kuşburnu, alıç, enginar ve karadut sirkeleri ile birlikte toplam yedi farklı sirke örneğinin antioksidan kapasiteleri 2,2-difenil-1-pikrilhidrazil (DPPH) ve galvinoksil yöntemleri kullanılarak belirlenmiştir. Çalışmanın sonucunda test edilen sirke örneklerinin antioksidan kapasite düzeyleri yüksekten düşüğe doğru sıralandığında DPPH yöntemine göre: nar $>$ kuşburnu $>$ alıç $>$ karadut $>$ enginar $>$ üzüm $>$ elma şeklinde olduğu ve galvinoksil yönteminde ise: nar $>$ kuşburnu $>$ alıç $>$ enginar $>$ karadut $>$ üzüm $>$ elma şeklinde olduğu görülmüş̧ür. Bu sonuçlara göre enginar ve karadut sirkeleri hariç test edilen sirke örneklerinin antioksidan özelliklerinin her iki yöntemle de benzer sonuçlar sergilediği görülmektedir. Enginar ile karadut sirkelerinin DPPH ve galvinoksil yöntemlerine göre farklı sonuçlar vermesi; farklı metotlar kullanmanın antioksidan kapasite düzeylerinin belirlenmesinde daha doğru sonuçlar elde edilmesindeki önemini göstermektedir.
\end{abstract}

Anahtar kelimeler: Antioksidan kapasite, DPPH radikali, Galvinoksil radikali, Sirke.

\section{The Evaluation of the Antioxidant Capacity Levels of Some Common and Uncommon Vinegars}

\begin{abstract}
Vinegar is a fermentation product obtained by using fermentable different raw materials. Vinegar has been used by many civilizations since ancient times and many different functions such as sweetening and disinfection in kitchens. It has also many positive effects on health with its antimicrobial, antioxidant, antidiabetic and anticarcinogenic properties with the help of various phenolic compounds, amino acids, vitamins and organic acids. In this study, the antioxidant capacities of the seven vinegar samples, including the rare rhizome, hawthorn, artichoke and black mulberry vinegars, along with the grape, apple and pomegranate vinegar found in the grocery stores, were determined by using DPPH and galvinoxyl methods. When the antioxidant capacity levels of the vinegar samples are ordered from high to low, according to the DPPH method: pomegranate > rosehip > hawthorn $>$ black mulberry $>$ artichoke $>$ grapes $>$ apple and in galvinoxyl method: pomegranate > rosehip > hawthorn > artichoke $>$ black mulberry $>$ grape $>$ apple. According to these results, the antioxidant properties of the vinegar samples tested with the exception of artichoke and black mulberry vinegar showed similar results with respect to both antioxidant capacity methods. Artichoke and black mulberry vinegars gave different results according to DPPH and galvinoxyl methods which proved the importance of using different methods in obtaining more accurate results in determining the antioxidant capacity levels.
\end{abstract}

Keywords: Antioxidant capacity, DPPH radical, Galvinoxyl radical, Vinegar.

*Sorumlu yazar: $\frac{\text { mkonus@yyu.edu.tr }}{\text { Geliş Tarihi: } 29.05 .2019, \text { Kabul Tarihi: 01.08.2019 }}$ 


\section{Giriş}

Sirke mayalanabilir karbon kaynağına sahip farklı hammaddelerden elde edilebilen bir fermantasyon ürünüdür [1]. Eskiden beri birçok farklı uygarlık tarafından kullanılan sirke birçok işleve sahiptir. Mutfaklarda lezzet artırma ve dezenfeksiyon amacıyla kullanılmanın yansıra tıbbi amaçlarla da kullanılmıştır [2]. Sirke içerisinde barındırdığ̣ ç̧eşitli fenolik bileşikler, aminoasitler, vitaminler, organik asitler ve melanoidler sayesinde sahip olduğu antimikrobiyal, antioksidan, antidiyabetik ve antikarsinojenik özellikleri ile insan sağlığı üzerinde birçok faydalı etkiye sahiptir [3].

Serbest radikaller, son yörüngesinde bir ya da birden fazla eşlenmemiş elektron taşıyan yüksek oranda reaktif moleküllerdir [4]. Kararsız olan bu moleküller diğer moleküllerle tepkimeye girerek istenmeyen oksidasyon reaksiyonlarına neden olmaktadırlar. Böylece organizmada proteinler, lipitler ve nükleik asitlerdeki bozukluklar, membran bütünlüğünün bozulması, genetik mutasyonlar şeklinde birçok hasara neden olmaktadırlar [5]. Antioksidanlar ise serbest radikalleri süpürerek hücrenin hasar görmesini engelleyen ve genellikle yapısında fenolik grup taşıyan moleküllerdir [6]. Antioksidan moleküller vücut tarafindan üretilebilirler ya da gıdalar aracılığıyla vücuda alınabilmektedirler [7]. Gıdaların sahip oldukları toplam antioksidan kapasiteyi belirlemek için günümüzde birçok biyokimyasal yöntem mevcuttur. Bu yöntemler, ölçüm için kullanıldıkları radikalin özelliğine bağlı olarak farklı sonuçlar verebilmektedirler [8]. Örneğin, DPPH yönteminde kararlı bir azot radikali kullanılmakta olup antioksidan kapasite belirlemelerinde yaygın olarak kullanılan yöntemlerin başında gelmektedir. Ayrıca, galvinoksil yönteminde ise bir karbon radikali kullanılmakta olup normal metabolik faaliyetler esnasında oluşan radikallere oldukça benzerdir [9]. Galvinoksil yöntemi antioksidan kapasite belirleme çalışmalarında DPPH yöntemi kadar yaygın kullanılan bir yöntem olmamasına rağmen bu yöntemde kullanılan karbon radikalinin insan metabolizmasına uygunluğundan dolayı bu çalışmada kullanılması tercih edilmiştir.

Bu çalışmada, marketlerde yaygın bulunan ve kullanılan üzüm, elma ve nar sirkelerinin yanı sıra nadir bulunan kuşburnu, alı̧, enginar ve karadut sirkeleri ile birlikte toplam yedi farklı sirke örneğinin antioksidan kapasiteleri DPPH ve galvinoksil yöntemleri kullanılarak belirlenmiştir. Böylece, test edilen sirke örneklerinin antioksidan kapasiteleri birden fazla yöntem ile ölçülerek, elde edilen sonuçların tutarlılı̆̆ değerlendirilmiştir.

\section{Materyal ve Yöntem}

\subsection{Materyal}

Bu çalışmada ticari olarak satışı yapılan yaygın üç farklı sirke çeşidi (üzüm, elma ve nar) ile birlikte marketlerde nadir bulunan ancak sanal ortamdaki alış-veriş sitelerinde satışı yapılan dört farklı sirke çeşidi (kuşburnu, alıç, enginar ve karadut) kullanılmıştır. Sirke örneklerinin marka ve içerik bilgileri Tablo 1'de belirtilmiştir. Bu sirkelerin etiket bilgilerine bakıldığında yaygın olarak satılan sirkelerin hepsinde katk1 maddesi olarak sodyum metabisülfit bulunduğu belirtilirken, yaygın bulunmayan sirkelerde ise herhangi bir katkı maddesi bulunmadığ belirtilmektedir. Tümü Tarım ve Orman Bakanlığı'ndan onaylı olan ve yaygın bulunan sirkeler üzüm, elma ve nar sirkeleri yerel marketlerden temin edildi. Yaygın bulunmayan sirkeler ise internetten sanal alış-veriş sitelerinden sipariş edilerek temin edildi. Temin edilen tüm sirke örnekleri deney gününe kadar $+4{ }^{\circ} \mathrm{C}$ dolapta muhafaza edildi.

Tablo 1. Test edilen sirke örneklerinin marka ve içerik bilgileri

\begin{tabular}{lll}
\hline Marka & Ürün & İçerik \\
\hline \multirow{2}{*}{ Köhne } & Üzüm sirkesi & Üzüm sirkesi, antioksidan (sodyum metabisülfit) \\
& Nar sirkesi & Nar sirkesi, antioksidan (sodyum metabisülfit) \\
& Elma sirkesi & Elma sirkesi, antioksidan (sodyum metabisülfit) \\
\hline \multirow{2}{*}{ Nahita } & Kuşburnu sirkesi & $\% 100$ Kuşburnu sirkesi \\
& Enginar sirkesi & $\% 100$ Enginar sirkesi \\
\hline Naturelife & Alıç sirkesi & $\% 100$ Alıç sirkesi \\
\hline Sirkecizade & Karadut sirkesi & $\% 100$ Karadut sirkesi \\
\hline
\end{tabular}




\subsection{Yöntem}

\subsubsection{DPPH (2,2-difenil-1-pikrilhidrazil) yöntemi}

Blois [10]' in DPPH yöntemi modifiye edilerek test edilen sirkelerin radikal süpürme kapasiteleri belirlendi. DPPH, kahverengi şişeler içerisinde konsantrasyonu $400 \mu \mathrm{M}$ olacak şekilde saf etanol ile çözdürüldü. Tamamen çözünmesi için DPPH ultrasonikatör içerisinde 30 dakika bekletildi. Test edilen sirkeler etanol ile seyreltilerek beş farklı konsantrasyon hazırlandı. Nar sirkesi için 79,5-1272, kuşburnu sirkesi için 62,5-1000, elma sirkesi için 2,5-47,5, üzüm sirkesi için 7,9-127,9, enginar sirkesi için 25400, karadut sirkesi için 16,7-266,6 ve alıç sirkesi için 25-400 kat seyreltme oranı kullanıldı. Standart madde olarak kullanılan askorbik asit için ise 5,32-85,08 $\mu \mathrm{M}$ konsantrasyon aralığ asit ile gerçekleştirilen deneyler hem laboratuvar koşullarında DPPH ve galvinoksil metotlarının başarılı şekilde uygulandığının kanıtlanması hem de sirkelerin toplam antioksidan kapasiteleri için referans teşkil etmesi için uygulanmıştır. Diğer taraftan, sirkelerin toplam antioksidan kapasitelerinin birbirleriyle karşılaştırılmalarında, basitçe, seyreltme faktöründen faydalanılmışıı. Her konsantrasyon ve kör (blank) için üçer örnek hazırlandı. Her örnek son konsantrasyonu $100 \mu \mathrm{M}$ DPPH olan ortamda 30 dakika boyunca oda sıcaklığında inkübe edildi. İnkübasyondan sonra UV/VIS spektrofotometrede 517 nm'de referansa (etanol) karşı okundu. Tüm ölçümler üçer tekrar olarak gerçekleştirildi. Radikal yakalama aktivitesi (\% RSA) Eşitlik 1'de belirtildiği gibi hesaplandı.

\% RSA=((KörAbs-ÖrnekAbs) $) /$ KörAbs $\times 100$

\subsubsection{Galvinoksil yöntemi}

Shi ve Niki [11] galvinoksil metodu optimize edilerek uygulandı. Bu yöntemde, $160 \mu \mathrm{M}$ olacak şekilde galvinoksil solüsyonu etanol ile hazırlandı. Test edilen sirkeler ve standart olarak kullanılan troloks(E vitamini analoğu) saf etanolde çözülerek beş farklı konsantrasyon olacak şekilde saf etanol ile seyreltmeler yapıldı. Nar sirkesi için 199,5-3192, kuşburnu sirkesi için 199,5-3192, elma sirkesi için 4,9-79, üzüm sirkesi için 16,6-266, enginar sirkesi için 66,7-1066,7, karadut sirkesi için 33,3-533,3 ve alıç sirkesi için 135,7-2171,4 kat seyreltme oranı kullanıldı. Standart madde olarak kullanılan troloks için ise $0,25-2,8 \mu \mathrm{M}$ konsantrasyon aralığ kullanıldı. Her konsantrasyon ve kör için üçer örnek hazırlandı. Her tüpe farklı konsantrasyonlarda hazırlanmış maddelerden eklenerek son konsantrasyonu $8 \mu \mathrm{M}$ galvinoksil olan çözelti içinde 20 dakika karanlık ortamda inkübasyona alındı ve spektrofotometrede 428 nm'de referansa (etanol) karşı okuma yapıldı. Tüm ölçümler üç tekrar olarak gerçekleştirildi. \% Radikal yakalama aktivitesi "Eşitlik 1" de belirtilen formül kullanılarak hesaplandı.

\section{Bulgular ve Tartışma}

\subsection{DPPH yöntemi sonuçları}

En yaygın antioksidan kapasite yöntemlerinden biri olan DPPH yönteminde bir azot radikali olan $\mathrm{DPPH} \bullet$ radikali kullanılmaktadır. Bu yöntem başlangıçta mor renkte olan DPPH• radikalinin antioksidan madde etkisiyle DPPH-H formuna indirgenmesiyle meydana gelen renk değişiminin $517 \mathrm{~nm}$ 'de ölçülmesi ve böylece süpürülen radikal miktarının hesaplanması prensibine dayanmaktadır [12]. Şekil 1 'de DPPH yönteminde standart madde olarak kullanılan askorbik asidin radikal süpürme aktivitesini gösteren grafik görülmektedir. Grafikteki denkleme göre DPPH radikalinin \%50'sini inhibe eden askorbik asit miktarı 33,98 $\mu \mathrm{M}$ olarak hesaplanmıştır.

Bu çalışmada DPPH yöntemiyle antioksidan kapasiteleri test edilen sirke örneklerinin radikalin yarısını inhibe eden seyreltme faktörü SF50 (radikalin \%50'sini inhibe eden seyreltme faktörü) olarak ifade edildi. SF50 değeri bu çalışmada radikalin yarısını inhibe eden seyreltme oranını ifade ettiğinden dolayı bu değer arttıkça ortamdaki sirke konsantrasyonu azalacaktır. Bu yüzden SF50 değeri arttıkça radikal süpürme aktivitesi de artacaktır; yüksek oranda seyreltilen sirke yine de radikalin yarısını süpürecek aktiviteye sahip demektir. DPPH metodunda antioksidan kapasiteleri test edilen sirke örneklerinin SF50 değerleri Şekil 2'de verilmiştir. Bu değerlere göre test edilen sirke örneklerinin 
antioksidan kapasiteleri yüksekten düşüğe doğru: nar $>$ kuşburnu $>$ alı̧ $>$ karadut $>$ enginar $>$ üzüm $>$ elma şeklinde olduğu görülmektedir.

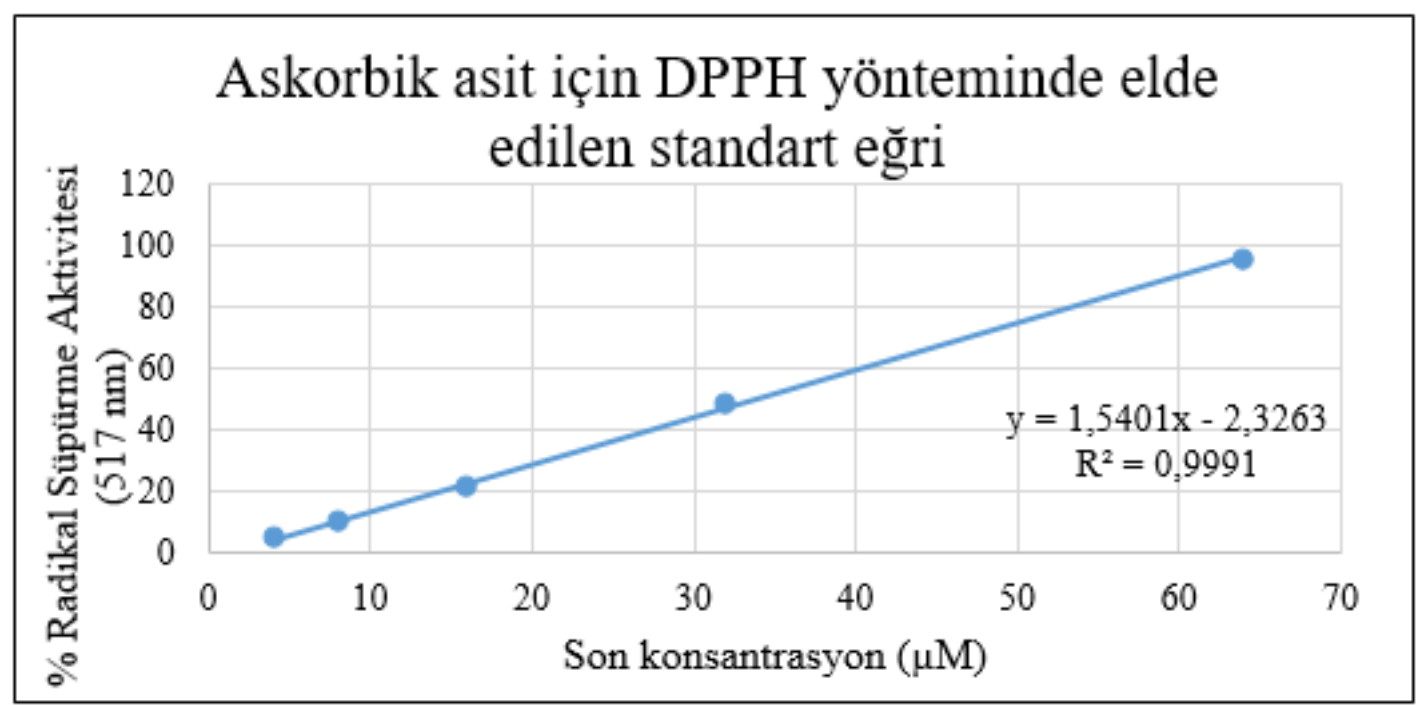

Şekil 1. DPPH yönteminde askorbik asidin $517 \mathrm{~nm}$ 'deki standart eğrisi

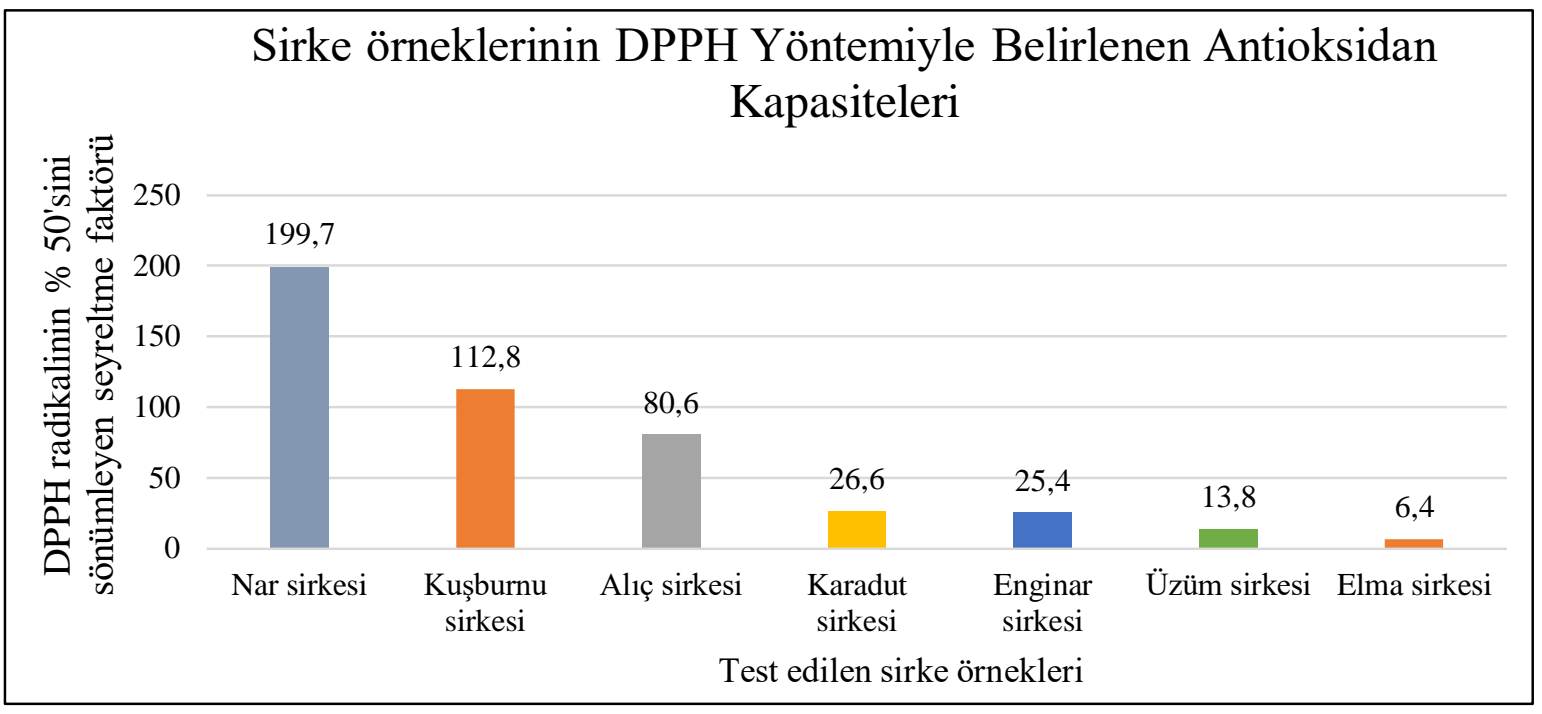

Şekil 2. DPPH yöntemiyle test edilen sirke örneklerinin $\mathrm{SF}_{50}$ değerlerinin kıyaslanması

DPPH yönteminde en yüksek antioksidan kapasitenin nar sirkesinde olduğu tespit edilirken en düşük antioksidan kapasitenin elma sirkesinde olduğu tespit edildi. Ayrıca, nar ve kuşburnu sirkelerinin antioksidan kapasitelerinin test edilen alıç, karadut, enginar, üzüm ve elma sirkelerinden yüksek olması da benzer şekilde bu sirkelerin içeriğindeki fenolik ve flavonoid maddelerin daha yüksek olması nedeniyle olabilir. Yapılan çalışmalarda, antioksidan kapasitenin total flavonoid [13] ve total fenolik madde [14] içeriğiyle doğru orantılı olarak artışlar gösterdiği rapor edilmiştir.

Antioksidan kapasite için önemli olan diğer bir faktör de bu sirke örneklerinin sahip olduğu vitamin içeriğidir. Örneğin, C vitamini ile yapılan çalışmalarda kuşburnunda yüksek miktarda C vitamini bulunduğu [15] ve bunun da antioksidan aktivitenin artışına katkıda bulunduğu rapor edilmiştir [16]. Buna karşın, bu çalışmada nar sirkesinin antioksidan içeriğinin kuşburnu sirkesinden daha yüksek olduğu görülmüsstür. Bunun nedeni ise nar sirkesinde katk1 maddesi olarak kullanılan sodyum metabisülfitten kaynaklanmış olabilir [17]. 


\subsection{Galvinoksil yöntemi sonuçları}

Bir ferromanyetik radikal olan galvinoksil radikali $428 \mathrm{~nm}$ 'de maksimum soğuruma sahiptir. Galvinoksil radikali hidrojen veren antioksidan maddeler tarafindan indirgenebilmektedir [18]. Başlangıçta sarımsı bir renkte olan bu radikal antioksidan madde tarafından indirgendiğinde bu renkte bir açılma meydana gelir. Meydana gelen renk değişimi spektrofotometre ile $428 \mathrm{~nm}$ 'de ölçülerek radikal süpürme aktivitesi hesaplanır.

Şekil 3'te galvinoksil yönteminde standart madde olarak kullanılan troloksun radikal süpürme aktivitesini gösteren grafik görülmektedir. Grafikteki denkleme göre galvinoksil radikalinin \%50'sini inhibe eden troloks miktarı 1,46 $\mu \mathrm{M}$ olarak hesaplanır.

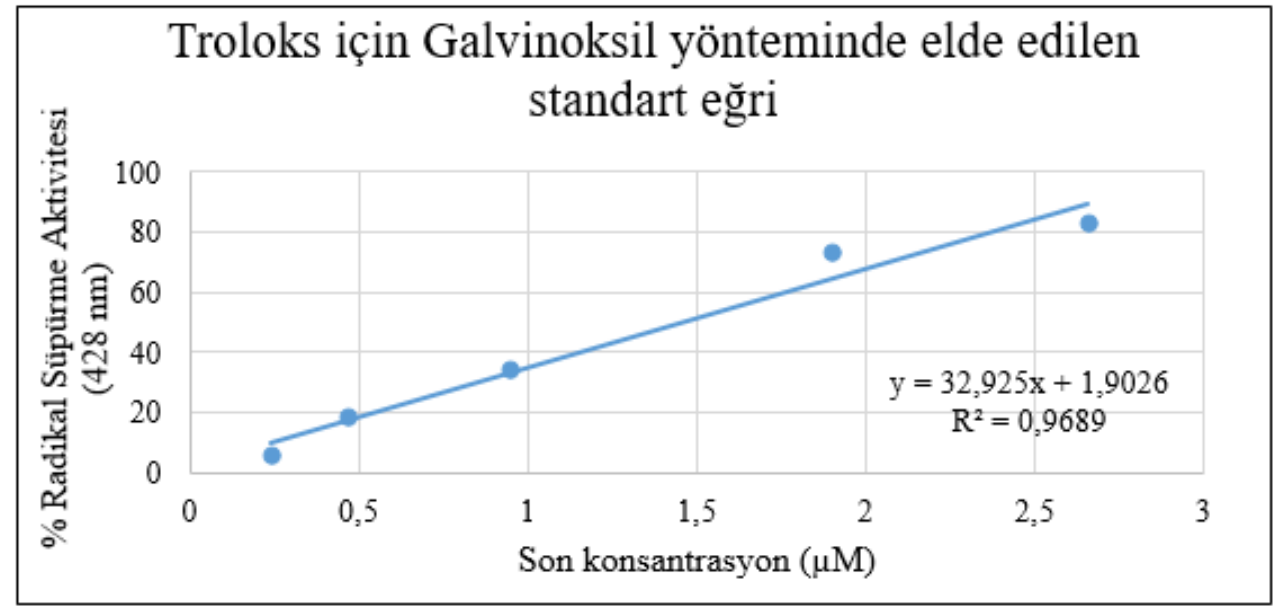

Şekil 3. Galvinoksil yönteminde troloksun 428 nm'deki standart eğrisi

$\mathrm{Bu}$ yöntemde test edilen sirke örneklerinin radikal süpürme aktivitelerini test etmek için DPPH yönteminde olduğu gibi SF50 değerleri kullanıldı. Benzer şekilde, SF50 değeri radikalin \% 50'sini inhibe eden seyreltme faktörünü ifade ettiğinden dolayı bu değer arttıkça galvinoksil radikalini süpürme aktivitesi de artacaktır.

Şekil 4'te galvinoksil yöntemine göre test edilen sirke örneklerinin SF50 değerlerinin kıyaslanması görülmektedir. Bu değerlere göre test edilen sirke örneklerinin radikal süpürme aktiviteleri yüksek düşüğe doğru: nar $>$ kuşburnu $>$ alıç $>$ enginar $>$ karadut $>$ üzüm $>$ elma şeklinde olduğu görülmektedir.

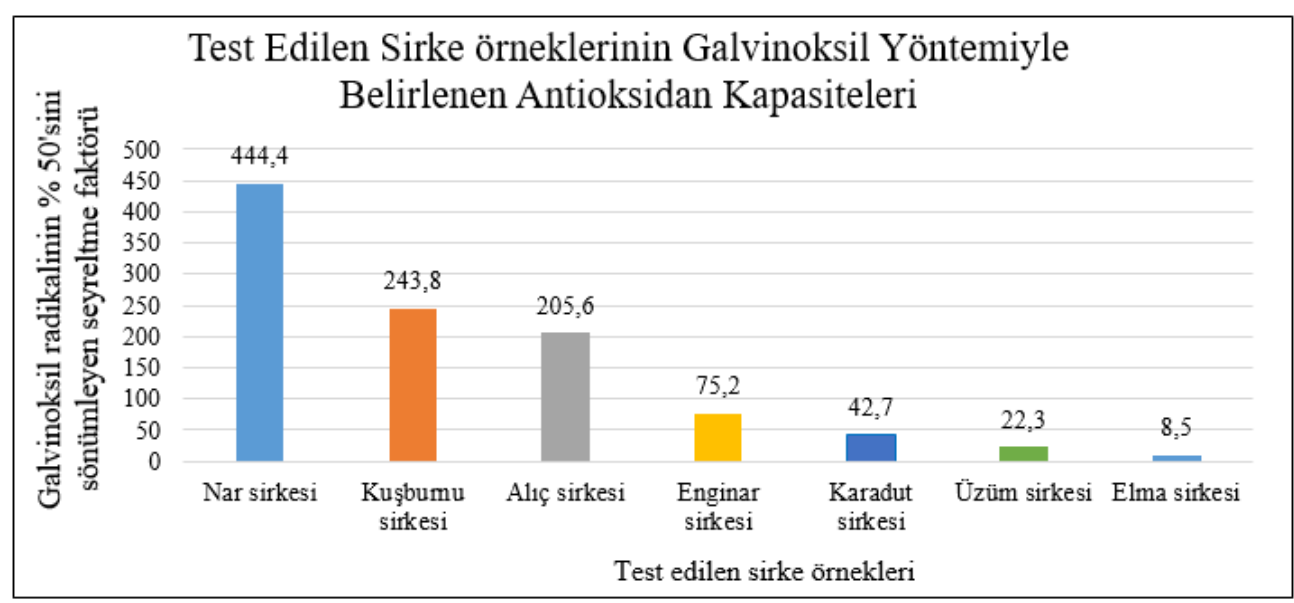

Şekil 4. Galvinoksil yöntemiyle test edilen sirke örneklerinin $\mathrm{SF}_{50}$ değerlerinin kıyaslanmas

$\mathrm{Bu}$ yöntemde test edilen sirkelerin antioksidan kapasitelerinin sonuçları DPPH yöntemi ile bulunan sonuçlara oldukça benzer şekilde olduğu (karadut ve enginar sirkelerinin kendi aralarındaki sıralama hariç) görüldü. Bu da yaygın olarak kullanılmayan galvinoksil yönteminin de DPPH yöntemine 
paralel sonuçlar verebildiğini ve DPPH yöntemiyle uyumlu bir şekilde kullanılabilecek bir yöntem olabileceğini göstermektedir.

DPPH yöntemi sonuçlarına göre enginar sirkesi $(\mathrm{SF} 50=25,4)$ ile karadut sirkesinin $(\mathrm{SF} 50=26,6)$ SF50 sonuçları birbirine oldukça yakın çıkmasına karşın, galvinoksil metodunda ise SF50 değerleri sırasıyla 75,2 ve 42,8 olmuştur. Bu sonuçlarda bize, farklı metotlar kullanmanın antioksidan kapasite düzeylerinin belirlenmesinde daha doğru sonuçlar elde edilmesindeki önemini göstermektedir.

Enginar ve karadutta ortak olarak klorojenik asit molekülleri bulunurken inulin sadece enginarda yaygın olarak bulunurken antosiyanin ise sadece karadutta bulunmaktadır [19-22]. Bu yüzden enginar ile karadut sirkelerinin antioksidan kapasitelerinin DPPH ve galvinoksil yöntemlerine göre farklılık göstermesinin sebebi olarak enginardaki inulin ile karadutta bulunan antosiyanin maddelerinin, prosedürlerdeki mevcut radikallerle farklı şekillerde ve/veya oranlarda etkileşmeleri düşünülebilir.

\section{Sonuç ve Öneriler}

Bu çalışmada yaygın olarak marketlerde bulunan üzüm, elma ve nar sirkelerinin yanı sıra nadir bulunan kuşburnu, alıç, enginar ve karadut sirkeleri ile birlikte toplam yedi sirke örneğinin antioksidan kapasiteleri DPPH ve galvinoksil yöntemleri kullanılarak belirlenmiştir. Test edilen sirke örneklerinin antioksidan kapasite düzeyleri yüksekten düşüğe doğru sıralandığında DPPH yöntemine göre: nar > kuşburnu $>$ alıç $>$ karadut $>$ enginar $>$ üzüm $>$ elma şeklinde olduğu ve galvinoksil yönteminde ise: nar $>$ kuşburnu $>$ alı̧ç $>$ enginar $>$ karadut $>$ üzüm $>$ elma şeklinde olduğu görülmektedir. Bu sonuçlara göre enginar ve karadut sirkeleri hariç test edilen sirke örneklerinin antioksidan özelliklerinin her iki antioksidan kapasite ölçüm yönteminde de paralellik gösterdiği görülmektedir. Enginar ve karadut sirkelerinde farklılık görülmesinin olası neden veya nedenleri ise enginarda bulunan inulin ve karadutta bulunan antosiyanin maddelerinden test edilen radikallerle etkileşim farklılıklarından kaynaklandığ düşünülmektedir. Ayrıca, karadutta antioksidan aktivitenin başlıca kaynağının antosiyanin maddesi olduğu [23] rapor edilirken enginar sirkesinde güçlü radikal süpürme aktivitesi gösteren birçok madde (lupeol, scolymoside, apigenin, narirutin, kafeik asit, klorojenik asit, ve ferulik asit) bulunduğu yapılan çalışmalarda belirtilmiştir [24-26]. Bunun da enginar ve karadut sirkelerinin antioksidan aktivitelerindeki farklılığın diğer bir nedeni olabileceği varsayılmaktadır.

DPPH yöntemi yaygın olarak kullanılan bir antioksidan kapasite yöntemidir. Buna karşın galvinoksil yöntemi daha nadir kullanılmaktadır. Bu çalışmada, galvinoksil ve DPPH yöntemlerinde benzer sonuçlar elde edilmesi galvinoksil yönteminin DPPH yöntemine hem bir alternatif hemde test edilen sonuçların teyit edilmesinde kullanılabilecek bir antioksidan kapasite yöntemi olduğunu göstermektedir. Ayrıca galvinoksil radikali bir karbon radikali olduğundan vücut metabolizmasında oluşan radikallere oldukça benzerdir [9]. Bu yüzden vücut metabolizmasına uygunluğu DPPH radikaline (azot radikali) göre daha fazladır.

Bu çalışmada kullanılan sirke örneklerinden nar, üzüm ve elma sirkeleri katkı maddesi olarak sodyum metabisülfit içerirken kuşburnu, alıç, karadut ve enginar sirkeleri herhangi bir katkı maddesi içermemektedir. Sodyum metabisülfitin antioksidan kapasiteye katkı sağladığı literatürde rapor edilmesine rağmen [17], bu çalışmada sodyum metabisülfit içermeyen örneklerin nar sirkesi hariç diğer örneklere (üzüm ve elma) göre daha yüksek antioksidan kapasiteye sahip olduğu görülmüştür.

\section{Yazarların Katkısı}

Yazarlar çalışmanın tasarımında, deneylerde ve makale yazımında eşit oranda katkıda bulunmuşlardır.

\section{Çıkar Çatışması Beyanı}

Yazarlar arasında herhangi bir çıkar çatışması bulunmamaktadır.

\section{Araştırma ve Yayın Etiği Beyanı}

Yapılan çalışmada, araştırma ve yayın etiğine uyulmuştur. 


\section{Kaynaklar}

[1] Öztürk A., Özdemir Y., Göksel Z. 2009. Elma Sirkesi Ve Teröpatik Etkileri. Tarım Bilimleri Araştırma Dergisi, 1: 155-158.

[2] Altunbağ E., Zencir E. 2018. Türk Ve Akdeniz Yemeklerinde Sirke Kullanımı. Journal of Gastronomy, Hospitality And Travel, 1 (2): 45-54.

[3] Şengün İ.Y., Kılıç G. 2018. Dut Sirkesinin Mikrobiyolojik, Fiziksel, Kimyasal, Antiradikal ve Antimikrobiyal Özellikleri. Akademik Gıda, 16 (2): 168-175.

[4] Sohal R.S. 1993. The free radical hypothesis of aging: an appraisal of the current status. Aging Clinical and Experimental Research, 5 (1): 3-17.

[5] Memişoğulları R. 2005. Diyabette serbest radikallerin rolü ve antioksidanların etkisi. Düzce Tıp Fakültesi Dergisi, 3: 30-39.

[6] Kähkönen M.P., Hopia A.I., Vuorela H.J., Rauha J.P., Pihlaja K., Kujala T.S., \& Heinonen, M. 1999. Antioxidant Activity Of Plant Extracts Containing Phenolic Compounds. Journal of agricultural and food chemistry, 47 (10): 3954-3962.

[7] Yavaşer R. 2011. Doğal Ve Sentetik Antioksidan Bileşiklerin Antioksidan Kapasitelerinin Karşılaştırılması. Yüksek Lisans Tezi, Adnan Menderes Üniversitesi, Fen Bilimleri Enstitüsü, Aydin.

[8] Prakash A., Rigelhof F., MIller E. 2001. Antioxidant activity. Medallion laboratories analytical progress, 19 (2): 1-4.

[9] Tirzitis G., Bartosz G. 2010. Determination of antiradical and antioxidant activity: basic principles and new insights. Acta Biochimica Polonica, 57 (2).

[10] Blois M.S. 1958. Antioxidant determinations by the use of a stable free radical. Nature, 181 (4617): 1199.

[11] Shi H., Niki E. 1998. Stoichiometric and kinetic studies on Ginkgo biloba extract and related antioxidants. Lipids, 33 (4): 365.

[12] Özenç B. 2011. Fumaria officinalis'in Antioksidan Aktivitesinin Belirlenmesi. Doktora Tezi, Selçuk Üniversitesi, Fen Bilimleri Enstitüsü, Konya.

[13] Turgut D.Y., Seydim A.C. 2013. Akdeniz Bölgesinde yetiştirilen bazı nar (Punica granatum L.) çeşit ve genotiplerinin fenolik bileşenleri ve antioksidan aktivitelerinin belirlenmesi. Akademik Gida, 11 (2): 51-59.

[14] Bakır S. 2014. Bazı Sirke Çeşitlerinin Fenolik Madde İçeriği Ve İn Vitro Biyoerişebilirliğinin Ve Üzüm İle Elma Sirkesi Üretimi Sırasında Antioksidan Aktivitede Meydana Gelen Değişimlerin İncelenmesi. Doktora Tezi, İstanbul Teknik Üniversitesi, Fen Bilimleri Enstitüsü, İstanbul.

[15] Yıldız Ü., Çelik F. 2011. Muradiye (Van) yöresinde doğal olarak yetişen kuşburnu (Rosa spp.) genetik kaynaklarının bazı fiziko-kimyasal özellikleri. Yüzüncü Yıl Üniversitesi Fen Bilimleri Enstitüsü Dergisi, 16 (2): 45-53.

[16] Aydın H. 2011. Bazı baharatların farklı ekstraktlarının antioksidan özelliklerinin belirlenmesi Yüksek Lisans Tezi, Trakya Üniversitesi, Fen Bilimleri Enstitüsü, Edirne.

[17] Hugh D., Grennan A., Abugila M.A., Weinkove C. 1987. Ascorbic acid as an antioxidant in measurements of catecholamines in plasma. Clinical chemistry, 33 (4): 569-571.

[18] Selçuk A.R. 2012. Galvinoksil radikali bazlı spektrofotometrik antioksidan aktivite tayin yöntemi ve yaygın olarak kullanılan diğer yöntemlerle kıyaslanması. Yüksek Lisans Tezi, Pamukkale Üniversitesi, Fen Bilimleri Enstitüsü, Denizli.

[19] Sonnante G., D'Amore R., Blanco E., Pierri C.L., De Palma M., Luo J., Martin C. 2010. Novel hydroxycinnamoyl-coenzyme A quinate transferase genes from artichoke are involved in the synthesis of chlorogenic acid. Plant Physiology, 153 (3): 1224-1238.

[20] Arfan M., Khan R., Rybarczyk A., Amarowicz R. 2012. Antioxidant activity of mulberry fruit extracts. International journal of molecular sciences, 13 (2): 2472-2480.

[21] Pagano I., Piccinelli A.L., Celano R., Campone L., Gazzerro P., De Falco E., Rastrelli L. 2016. Chemical profile and cellular antioxidant activity of artichoke by-products. Food \& function, 7 (12): 4841-4850.

[22] Budiman A., Aulifa D.L., Kusuma A.S.W., Sulastri A. 2017. Antibacterial and antioxidant activity of black mulberry (Morus nigra L.) Extract for acne treatment. Pharmacognosy Journal, $9(5)$. 
[23] Yiğit D., Ahmet M.A.V.İ., Aktaş M. 2008. Antioxidant activities of black mulberry (Morus nigra). Erzincan Üniversitesi Fen Bilimleri Enstitüsü Dergisi, 1 (2): 223-232.

[24] Wang M., Simon J.E., Aviles, I.F., He K., Zheng Q.Y., Tadmor Y. 2003. Analysis of antioxidative phenolic compounds in artichoke (Cynara scolymus L.). Journal of agricultural and Food Chemistry, 51 (3): 601-608.

[25] Azzini E., Bugianesi R., Romano F., Di Venere D., Miccadei S., Durazzo A., Maiani G. 2007. Absorption and metabolism of bioactive molecules after oral consumption of cooked edible heads of Cynara scolymus L.(cultivar Violetto di Provenza) in human subjects: a pilot study. British Journal of Nutrition, 97 (5): 963-969.

[26] Löhr G., Deters A., Hensel A. 2009. In vitro investigations of Cynara scolymus L. extract on cell physiology of HepG2 liver cells. Brazilian Journal of Pharmaceutical Sciences, 45 (2): 201-208. 